\title{
Induction of apoptosis by UV in the flat oyster, Ostrea edulis
}

\author{
Gervais Ophélie ${ }^{1}$, Renault Tristan ${ }^{1}$, Arzul Isabelle ${ }^{1, *}$
}

${ }^{1}$ Institut Français de Recherche pour l'Exploitation de la Mer (Ifremer), Unité Santé Génétique et Microbiologie des Mollusques (SG2M), Laboratoire Génétique et Pathologie des Mollusques Marins (LGPMM), Avenue de Mus de Loup, 17390 La Tremblade, France

* Corresponding author : Isabelle Arzul, Tel.: +33546762610 ; email address : iarzul@ifremer.fr

\begin{abstract}
:
Apoptosis is a fundamental feature in the development of many organisms and tissue systems. It is also a mechanism of host defense against environmental stress factors or pathogens by contributing to the elimination of infected cells. Hemocytes play a key role in defense mechanisms in invertebrates and previous studies have shown that physical or chemical stress can increase apoptosis in hemocytes in mollusks. However this phenomenon has rarely been investigated in bivalves especially in the flat oyster Ostrea edulis. The apoptotic response of hemocytes from flat oysters, O. edulis, was investigated after exposure to UV and dexamethasone, two agents known to induce apoptosis in vertebrates. Flow cytometry and microscopy were combined to demonstrate that apoptosis occurs in flat oyster hemocytes. Investigated parameters like intracytoplasmic calcium activity, mitochondrial membrane potential and phosphatidyl-serine externalization were significantly modulated in cells exposed to UV whereas dexamethasone only induced an increase of DNA fragmentation. Morphological changes were also observed on UV-treated cells using fluorescence microscopy and transmission electron microscopy. Our results confirm the apoptotic effect of UV on hemocytes of $O$. edulis and suggest that apoptosis is an important mechanism developed by the flat oyster against stress factors.
\end{abstract}

\section{Graphical abstract :}

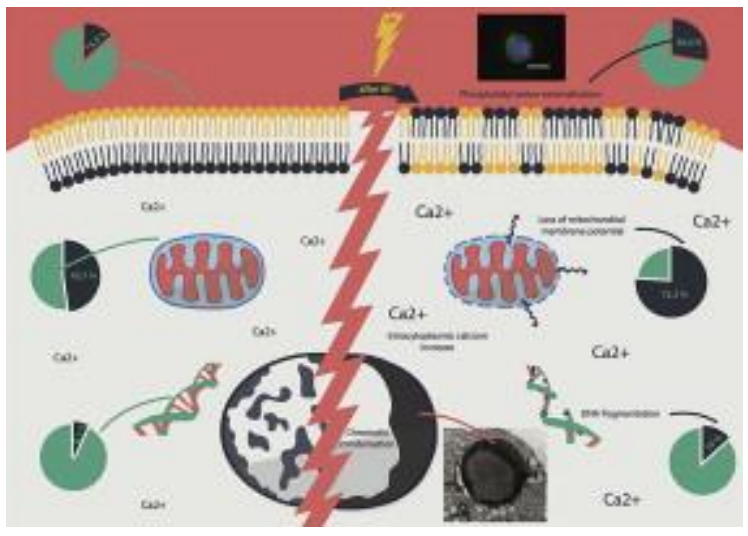




\section{Highlights}

Apoptosis in flat oysters was investigated in vitro by flow cytometry and microscopy. UV exposure induces significant modifications of tested apoptosis parameters. Hemocyte response was similar between two tested oyster populations. Apoptosis: an important mechanism developed by Ostrea edulis against stress factors.

Keywords : Apoptosis, hemocyte(s), oyster, Ostrea edulis, UV, flow cytometry, microscopy

\section{Introduction}

Apoptosis is a multifunctional process, which is involved in tissue and cellular homeostasis, embryonic development, immune defense against pathogens, and adaptive mechanism against environmental stresses [1,2]. Contrary to necrosis, apoptosis does not induce inflammation [1,3,4]. Apoptosis plays a key role in immune system by eliminating cells infected with pathogens [5-7] or cells subjected to various stress factors [2,8,9]. In mollusks, besides the anatomical and chemical barriers (mucus), immunity relies on cellular and soluble components of hemolymph, including hemocytes [4]. Hemocytes play a pivotal role in invertebrates notably by being involved in phagocytosis [10-12] and producing immune effectors including antimicrobial peptides and hydrolytic enzymes [13]. Previous studies have shown that stress factors like UV, toxic agent, heavy metals or toxic algae induce an increase of hemocytes apoptosis in mollusks [8,14-18]. 
This phenomenon results in numerous morphological and biochemical changes at the cellular level. Early morphological change consists in chromatin condensation along the nuclear membrane [19]. Cell blebbing is then observed while the nucleus appears condensed and is broken down into several fragments [7,20]. Although organists generally stay intact, cells are disintegrated in apoptotic bodies. These bodies can be phagocytized by other cells $[2,4,7,20]$.

Apoptosis can be triggered by two major pathways: (i) the intrinsic or mitochondrial pathway is activated in response to internal cellular damage and (ii) the extrinsic pathway is stimulated by external signal received from the environment. Several works have demonstrated that apoptosis can be activated through both pathways in bivalves. In the Mediterranean mussels Mytilus galloprovincialis, a modulation of genes involved in the intrinsic pathway such as p53, Bax, Bcl2 and BI-1 was described in hemocytes exposed to UV [21]. A homolog to Bcl2 was also reported from Pacific oyster hemocytes exposed to Ostreid Herpesvirus 1 (OsHV-1) [22].Some genes involved in the extrinsic pathway such as Fas ligand, TNF- $\alpha$, caspase 2 and caspase 8 have also been described in various mollusks $[17,23,24]$.

The flat oyster, O. edulis, is an endemic European oyster species. Its production has been threatened by overfishing and two protozoan parasites, Marteilia refringens, and Bonamia ostreae and is today in the OSPAR (Oslo and Paris Conventions for the protection of the marine environment of the North-East Atlantic) list of threatened and/or declining species and habitats (OSPAR agreement 2008-6).

In O. edulis, few studies related to apoptosis have been carried out up to now [23,25-27]. Experimental studies have shown modulation of genes involved in apoptosis and suggested that in flat oysters, O. edulis, apoptosis is involved in response to infection with the protozoan parasite B. ostreae [23,26,27]. A particular study reported apoptosis associated with gill lesions based on morphological modifications and fragmentation of DNA [28].

Considering the importance of apoptosis in response to pathogens or stress factors in mollusks and the lack of information in the flat oyster $O$. edulis, we have studied cellular changes in hemocytes from this oyster species. Oysters used in the present study were collected from two natural populations genetically different and originating from two different geographic locations [29].

The aim of this study is to investigate the effect of various stress factors on hemocyte apoptosis in the flat oyster. This work allowed us to select the most relevant parameters to 
describe apoptosis in our conditions and to better understand this process as a defense mechanism in marine bivalves.

\section{Materials and methods}

\subsection{Oysters}

Adult flat oysters (> two-year-old) Ostrea edulis were collected from two distinct natural beds in Quiberon Bay (Brittany, Atlantic Ocean) and Diana lagoon (Corsica, Mediterranean Sea) in France in October 2013. These populations are genetically distinct and previous works showed that they display different response against pathogen such as the parasite $B$. ostreae [29]. There were acclimatized in Ifremer's facilities (La Tremblade, Charente Maritime, France) for at least 14 days and maintained in raceways $(800 \mathrm{~L})$ with a constant flow of seawater enriched in phytoplankton (Skeletonema costacum, Isochrysis galbana and Tetraselmis suecica).

\subsection{Haemolymph collection}

Hemolymph was withdrawn from the adductor muscle of oysters with a $1 \mathrm{~mL}$ syringe and a needle of $0.60 \times 25 \mathrm{~mm}$. Hemolymphs were kept on ice to avoid cellular aggregation and were filtered between 60 and $100 \mu \mathrm{m}$ to remove debris and cell aggregates. Hemocytes were counted using a hemocytometer and concentration was adjusted at $5.10^{5}$ cells. $\mathrm{mL}^{-1}$ by adding $0.22 \mu \mathrm{m}$ filtered sea water (FSW).

\subsection{Apoptosis induction experiments}

\subsubsection{UV exposure}

Hemocytes were exposed for 45 min to UV (11 Watts, Atlantium) at room temperature in 24 well plates (Cellstar ${ }^{\circledR}$, Greiner Bio-One). Concurrently, control (= non-exposed hemocytes) was kept in the dark in the same conditions of temperature. After $45 \mathrm{~min}$ of exposure, both plates (exposed and non-exposed hemocytes) were maintained at $15^{\circ} \mathrm{C}$ in the dark until cell sampling. Cell suspensions were transferred to $1 \mathrm{~mL}$ tubes (Eppendorf) for analyses 1,3 and $5 \mathrm{~h}$ after $\mathrm{UV}$ exposure. Experiments were carried out three times and included two replicates for each condition.

\subsubsection{Dexamethasone exposure}


Hemocytes were exposed to dexamethasone (Apoptosis inducers set, GBiosciences) at 10 $\mu \mathrm{M}$ (final concentration) in 24 well plates (Cellstar®, Greiner Bio-One). Suspensions were kept at $15^{\circ} \mathrm{C}$ in the dark for 2,4 and $6 \mathrm{~h}$ of exposure. Non-exposed hemocytes were maintained in similar conditions of temperature in the dark. After incubation, cell suspensions were transferred to $1 \mathrm{~mL}$ tubes (Eppendorf). Experiments were performed three times and included two replicates for each condition.

\subsection{Flow cytometry analyses}

Apoptosis markers were analysed by flow cytometry using an EPICS XL 4 (Beckman Coulter) following settings previously determined by [30]. Results were depicted as cell cytograms and reported in log scale fluorescence level for each marker used.

\subsubsection{Intracytoplasmic calcium activity}

Intracytoplasmic calcium activity was evaluated by adding the fluorescent probe Fluo4/AM (Molecular Probes) at the final concentration of $2.5 \mu \mathrm{M}$ to $200 \mu \mathrm{L}$ of hemocyte suspensions. Cells were incubated for $2 \mathrm{~h}$ in the dark at room temperature. Labelled cells emit in the green (FL1: 500-550 nm).

\subsubsection{Mitochondrial membrane potential $(\Delta \Psi \mathrm{m})$}

Mitochondrial membrane potential was measured by adding $2.5 \mu \mathrm{L}$ of JC-10 dye (FluoProbes ${ }^{\circledR}$ ) at $0.5 \mu \mathrm{M}$ to $100 \mu \mathrm{L}$ of hemocyte suspensions. Tubes were incubated at $18^{\circ} \mathrm{C}$ during $30 \mathrm{~min}$ in the dark and transferred on ice for 5 minutes to stop cellular process. JC-10 dye selectively enters into mitochondria and its color changes depending on membrane potential. When $\Delta \Psi \mathrm{m}$ is low the predominant form is the monomer emitting green fluorescence (FL1), when membrane potential increases an accumulation of the aggregated form appears and emits orange fluorescence (FL2: $570 \mathrm{~nm}$ ).

\subsubsection{Phosphatidyl-serine externalization}

Phospholipid asymmetry of plasma membrane was measured using a commercial apoptosis detection kit (Eurobio). Hemocyte suspensions were centrifuged at $500 \mathrm{x} \mathrm{g}$ for 8 min at $4^{\circ} \mathrm{C}$. The supernatant was removed and cells were washed with $3 \mathrm{X}$ Phosphate-Buffered Saline (PBS). Two hundred $\mu \mathrm{L}$ of hemocyte suspensions $\left(5.10^{5}\right.$ cell. $\left.\mathrm{mL}^{-1}\right)$ were pelleted and suspended in $190 \mu \mathrm{L}$ of $3 \mathrm{X}$ Binding buffer. Ten $\mu \mathrm{L}$ of Annexin-V-FITC were added to cell suspensions and incubated for $20 \mathrm{~min}$ at room temperature. After incubation, cells were 
centrifuged $\left(500 \times \mathrm{g}, 8 \mathrm{~min}\right.$ at $\left.4^{\circ} \mathrm{C}\right)$, suspended in $185 \mu \mathrm{L}$ of $3 \mathrm{X}$ Binding buffer before adding $15 \mu \mathrm{L}$ of the viable propidium iodide (PI) (initial concentration: $20 \mu \mathrm{g} . \mathrm{mL}^{-1}$ ). Cell labelling with Annexin or with PI allowed identifying four cell populations: (i) cells that stain positive to Annexin V-FITC and negative for PI were undergoing apoptosis and emitted green fluorescence (FL1); (ii) cells positive to both Annexin V-FITC and PI (FL3: 560-670 nm) were either in the end stage of apoptosis, or were undergoing necrosis;(iii) negative cells were alive and (iv) cells positive only for PI were considered dead.

\subsubsection{Caspase activities}

Caspase activities were measured using the Vybrant ${ }^{\circledR}$ FAM Poly Caspases Assay Kit (Molecular Probes). After induction of apoptosis, $150 \mu \mathrm{L}$ of cell suspensions at $5.10^{5}$ cell.mL

${ }^{1}$ were centrifuged for $8 \mathrm{~min}$ at $500 \mathrm{x}$ g at $4^{\circ} \mathrm{C}$. Cells were resuspended in FSW. After adding $5 \mu \mathrm{L}$ of FLICA (Fluorochrome-Labeled Inhibitors of Caspases) 30X, cell suspensions were incubated $1 \mathrm{~h}$ in the dark at $15^{\circ} \mathrm{C}$. Cells were washed twice in $3 \mathrm{X}$ washing buffer. Finally, 2 $\mu \mathrm{L}$ of PI were added and suspensions were incubated $10 \mathrm{~min}$ on ice in the dark. Four populations were identified depending on the staining: (i) cells that stain positive to FLICA and negative for PI were considered as apoptotic cells (FL1); (ii) cells positive to both FLICA and PI (FL3) were necrotic cells; (iii) cells positive only for PI were considered dead and (iv) cells negative to both FLICA and PI were alive.

\subsubsection{Hemocyte populations}

Cell cytograms indicating cell size (forward scatter (FSC) values) and cell complexity (side scatter (SSC) values) allowed identifying two main populations of hemocytes: cells showing lowest FSC and SSC values were considered as hyalinocytes and cells showing highest FSC and SSC were considered as granular cells or granulocytes [31,32].

\subsection{DNA fragmentation (TUNEL)}

One hundred $\mu \mathrm{L}$ of hemocyte suspensions were deposited on glass slide and cytocentrifuged $\left(100 \mathrm{x} \mathrm{g}, 1 \mathrm{~min}, 4^{\circ} \mathrm{C}\right)$. Cells were fixed with $4 \%$ paraformaldehyde for $10 \mathrm{~min}$ at room temperature and kept at $-20^{\circ} \mathrm{C}$ after fixation. Cell permeabilization was carried out by incubating slides in $0.1 \mathrm{M}$ citrate buffer at pH6 and by heating them in a microwave (350W) for 5 min [33]. DNA fragmentation was detected using the In situ Cell Death Detection Kit, POD (Roche) according to the manufacturer's recommendations except that enzyme solution was half diluted. Positive controls consisted in slides treated with TURBO DNase (Ambion) 
during $10 \mathrm{~min}$ at $37^{\circ} \mathrm{C}$. Non-specific staining was checked by testing slides without adding the enzyme solution (Terminal deoxynucleotidyl transferase from calf thymus). Six slides were observed for each condition.

\subsection{Fluorescence microscope analysis}

UV-exposed and non-exposed hemocytes collected from oysters originating from Quiberon were observed under fluorescence microscope (Leica DFC3000 G). One hundred $\mu \mathrm{L}$ of cell suspensions were stained using Annexin-V or JC-10 using the same protocol used for flow cytometry, centrifuged $\left(100 \times \mathrm{g}, 1 \mathrm{~min}, 4^{\circ} \mathrm{C}\right)$ and fixed with $4 \%$ paraformaldehyde for $10 \mathrm{~min}$. Cell nuclei were stained by adding 4',6-diamidino-2-phenylindole (DAPI (2 $\mu \mathrm{g} / \mu \mathrm{L}$ of PBS)). After a 4 min incubation in the dark, slides were washed with $1 \mathrm{X}$ PBS. Appropriate images were extracted from LAS AF and manipulated with the ImageJ software. $\Delta \Psi \mathrm{m}$ values were calculated at the 590/530 emission fluorescence ratios $(n=30)$. Percentages of apoptotic cells were calculated by estimating the number of cells labelled with Annexin-V divided by number of observed cells.

\subsection{Transmission electron microscopy (TEM)}

Hemocyte suspensions $\left(1.10^{6}\right.$ cells $)$ were centrifuged at $500 \mathrm{x} \mathrm{g}$ for $8 \mathrm{~min}$ at $4^{\circ} \mathrm{C}$ and supernatant was eliminated. Samples were fixed in $3 \%$ glutaraldehyde solution for 1 day at $4^{\circ} \mathrm{C}$. Cells were washed 3 times with $0.4 \mathrm{M}$ cacodylate buffer and post-fixed with a solution of $1 \%$ osmium tetroxide for $1 \mathrm{~h}$ at $4^{\circ} \mathrm{C}$. Cells were washed twice again in $0.4 \mathrm{M}$ cacodylate buffer. After dehydration in successive baths of ethanol, and two baths of propylene oxide, samples were progressively impregnated and embedded in Epon. After polymerization at $60^{\circ} \mathrm{C}$, semi-thin sections were cut to $1 \mu \mathrm{m}$ thickness for quality control and then to $80-85 \mathrm{~nm}$ for examination on Leica ultracut (EM UC6), floated onto copper EM grids and stained with uracil acetate/Fahmys lead citrate (Lewis and Knight, 1977). The sections were examined using a transmission electron microscope (JEOL-JEM 1000). Four conditions were observed for oysters from Quiberon: non-treated cells at $4 \mathrm{~h}$ and UV-exposed cells at 2, 4 and $6 \mathrm{~h}$.

\subsection{Statistical analyses}

Flow cytometry data were analysed with Flowing software 2.5.1. Results were expressed as means \pm standard error. Two-way analysis of variance (ANOVA) followed by Bonferroni post-test were used to analyse differences between control and exposed hemocytes tested by flow cytometry and TUNEL using GraphPad Prism v.5.03. Two-way ANOVA and 
Bonferroni post-test were also used to compare hemocyte populations (hyalinocytes and granulocytes). A paired t-test was performed to compare intensity fluorescence ratio of $\Delta \Psi \mathrm{m}$.

\section{Results}

\subsection{Effect of $U V$ and dexamethasone on early apoptosis}

Effects of UV and dexamethasone on early apoptosis in hemocytes of flat oysters were evaluated by measuring the cytoplasmic calcium concentration (Fig. 1) and the $\Delta \Psi \mathrm{m}$ (Fig. 2) in exposed and non-exposed hemocytes. Two pools of hemocytes were presently tested: hemocytes collected from Quiberon oysters and hemocytes from Corsica oysters.

For the cytoplasmic calcium concentration, three different populations of cells were distinguished: population of cells with low, intermediate and high fluorescence corresponding to low, moderate and high cytoplasmic calcium concentration, respectively.

A significant increase of cells with high cytoplasmic calcium concentration was observed as soon as 2 hours post UV exposure $(\mathrm{p}<0.001)$ in hemocytes from Quiberon oysters and after 4 hours of UV exposure in hemocytes from Corsican oysters ( $<<0.01)$ (Fig. 1A and B). Dexamethasone did not induce any significant change in tested conditions whatever was the origin of the oysters (Fig. 1A and B). Time of incubation after UV or dexamethasone exposure did not impact this parameter.
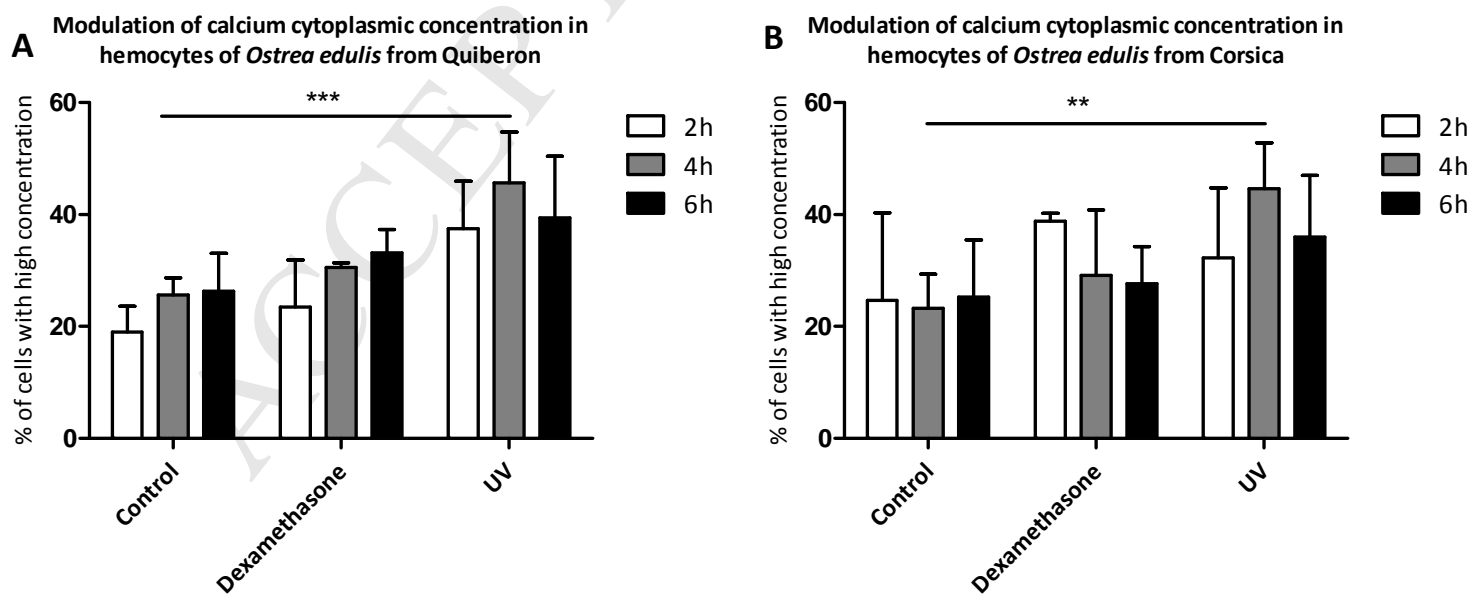

Figure 1. Modulation of calcium cytoplasmic concentration in hemocytes of Ostrea edulis. A and B: Percentages of cells with calcium cytoplasmic concentration for hemocytes of flat oyster from Quiberon (A) and Corsica (B) non-exposed (=control), exposed to dexamethasone or UV. Results represent the mean $\pm \mathrm{SD}$ of three experiments. $* * *(\mathrm{P}<0.001), * *(\mathrm{P}<0.01)$ 
The level of the mitochondrial membrane potential allowed identifying two cell 218 populations, with low and high $\Delta \Psi \mathrm{m}$. UV-treated cells showed a modification of the $\Delta \Psi \mathrm{m}$ 219 (Fig. 2A and 2B) while no change was observed in dexamethasone-treated cells. UV induced a significant increase of cells with low $\Delta \Psi \mathrm{m}$ as soon as 2 hours after UV exposure in hemocytes from Quiberon and Corsican oysters. Percentages of cells with low $\Delta \Psi \mathrm{m}$ remained stable whatever was the time of incubation after UV exposure.

Modulation of the $\Delta \Psi \mathrm{m}$ in UV treated hemocytes was also evaluated by epifluorescence microscopy (Fig. 2C). Non-exposed hemocytes showed more red staining, corresponding to aggregate JC-10, than UV-treated cells. Conversely, in UV-exposed, free JC-10 emitting green fluorescence, was more abundant than in control. A significant decrease of the fluorescence intensity ratio was noticed between UV treated cells (ratio=1.19 \pm 0.26 ) and nontreated cells (ratio $=2.16 \pm 0.66)$ at 6 hours after UV exposure (Fig. 2D).

\subsection{Plasma membrane modification and caspase activities}

Two additional apoptosis parameters were measured in hemocytes after UV and dexamethasone exposure: caspase activation (Fig. 3) and externalization of phosphatidylserine on plasma membranes (Fig. 4). Four populations of cells were described for these two parameters: alive, apoptotic, primary or secondary necrotic and dead cells (Fig. 3 and Fig. 4). 
A Modulation of mitochondria membrane potential in hemocytes of Ostrea edulis from Quiberon

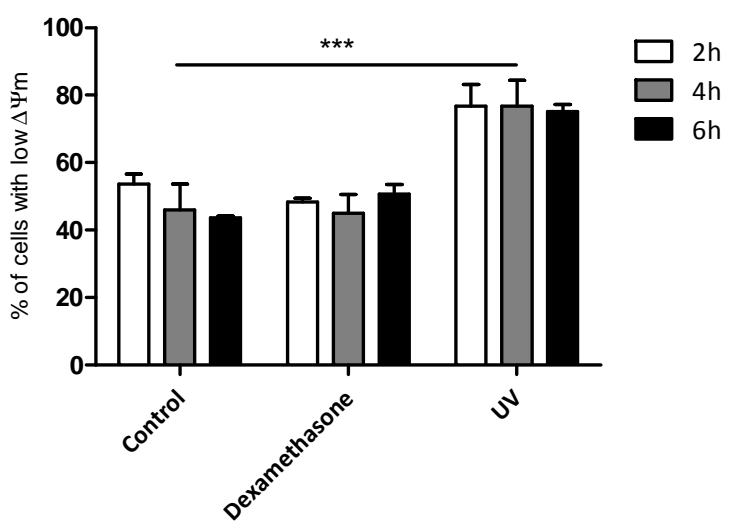

234

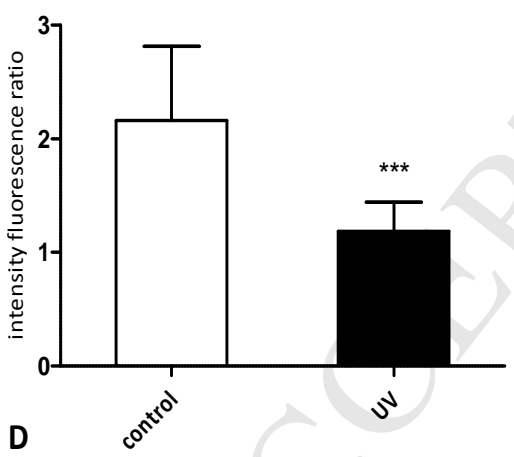

B

Modulation of mitochondrial membrane potential in hemocytes of Ostrea edulis from Corsica

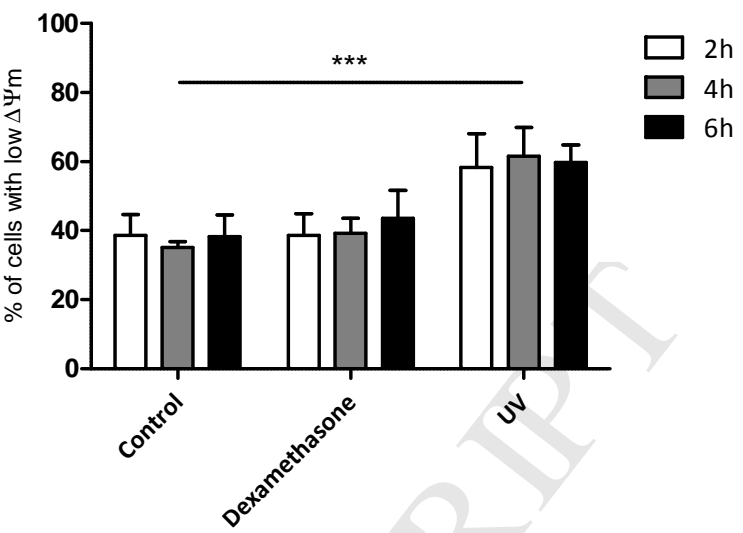

Aggregated

Free

C

DIC

DAPI
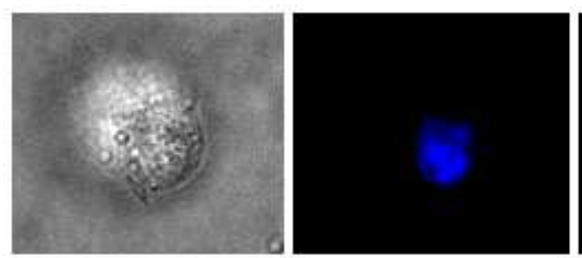

JC-10

JC-10
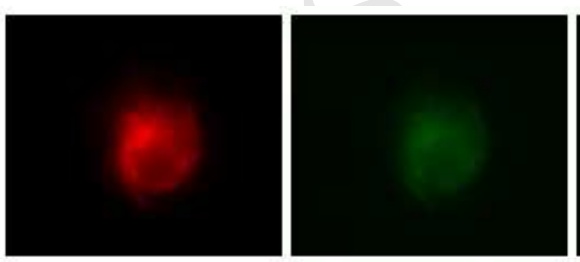

Merge
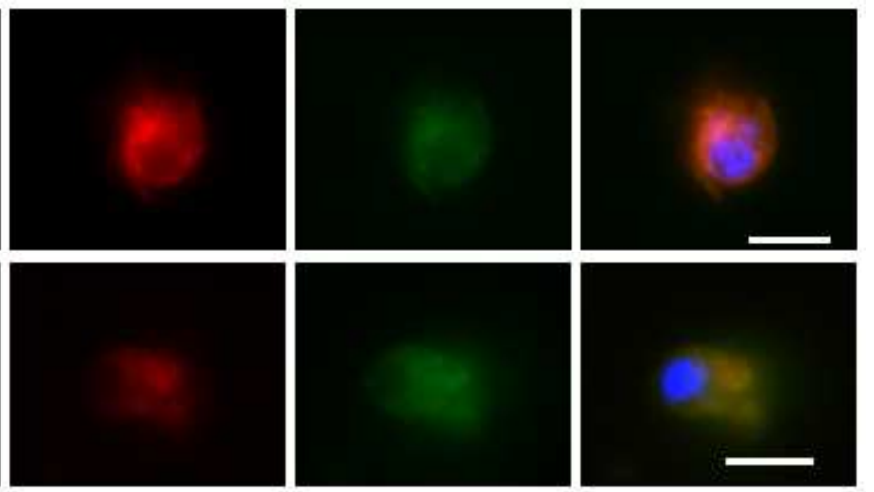

Figure 2. Modulation of mitochondrial membrane potential $(\Delta \Psi \mathrm{m})$ in hemocytes of Ostrea edulis. Percentages of cells with low $\Delta \Psi \mathrm{m}$ for hemocytes of oysters from Quiberon (A) and Corsica (B) non-exposed (=control), exposed to dexamethasone or UV. (C) $\Delta \Psi \mathrm{m}$ modification in non-exposed (=control) and UV-treated hemocytes of oysters from Quiberon, bar $=10 \mu \mathrm{m}$. (D) Intensity fluorescence ratio (590/530) of non-exposed (=control) and UV-treated hemocytes of oysters from Quiberon at 6 hours post exposure. Results represent the mean \pm SD of three experiments. 
For caspase activation, percentage of necrosis in the control was never above $7.4 \%$.

\section{1}

252

253

254

255

Percentages of cells that showed caspase activation were similar in control and in hemocytes treated with dexamethasone (Fig. 3A and B). Conversely, UV-exposure induced a significant increase of caspase activation in hemocytes from Quiberon oysters (Fig. 3A). Time of incubation did not modulate this parameter.
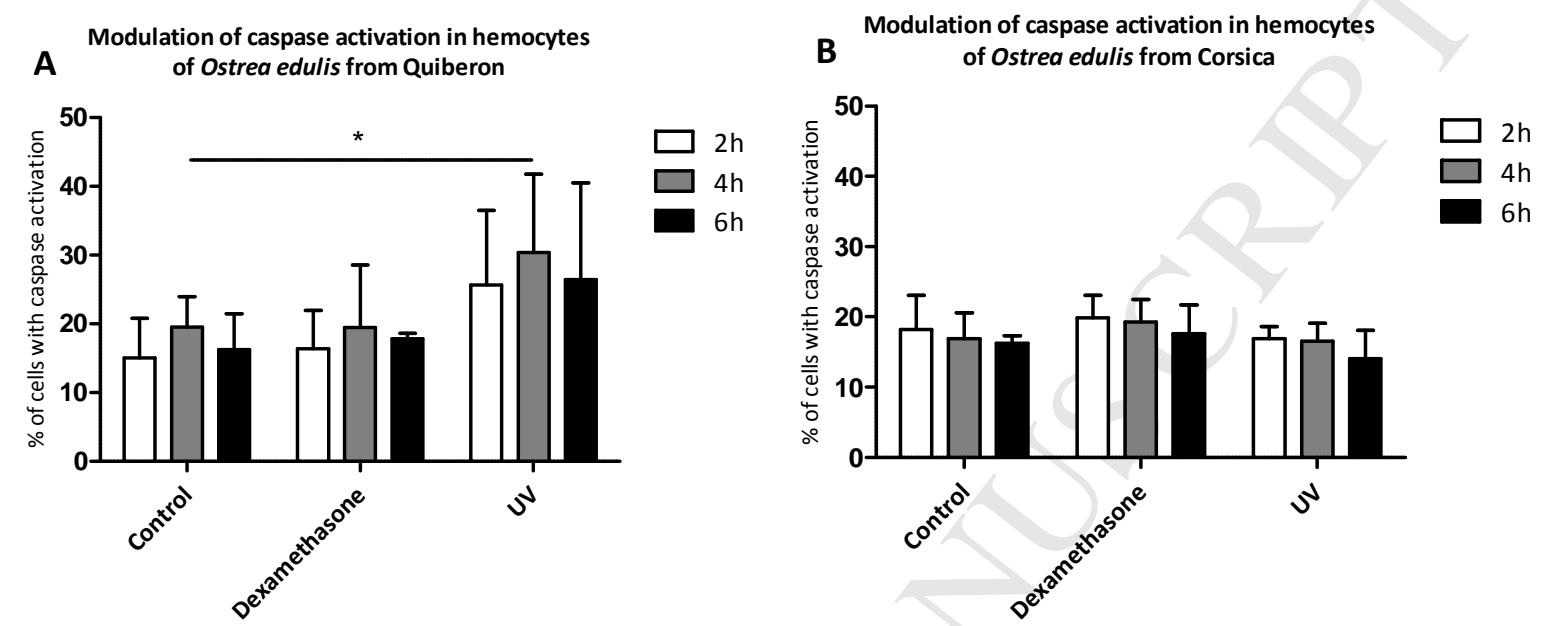

Figure 3. Modulation of caspase activation in hemocytes of Ostrea edulis. Percentages of caspase positive and IP negative hemocytes of oyster from Quiberon (A) and Corsica (B) non-exposed (=control) or exposed to dexamethasone and UV. Results represent the mean \pm SD of three experiments (one replicate for each experiment). $*(\mathrm{P}<0.05)$

For the externalization of phosphatidyl-serine, percentage of apoptosis and necrosis in the control was lower than $28 \%$ and $12 \%$, respectively. Dexamethasone did not induce any significant change in hemocytes of flat oysters whereas UV significantly increased the percentage of Annexin-V positive cells as soon as $2 \mathrm{~h}$ of UV exposure in hemocytes from Quiberon and Corsican oysters $(\mathrm{p}<0.001)$ (Fig. 4A and B). In addition, UV-treated cells showed an increase of secondary necrosis between 2 and 6 hours from $11.87 \% \pm 5.01$ to $19.78 \% \pm 2.86$, but only for hemocytes of oysters from Quiberon.

Modification of plasma membrane in UV treated hemocytes was also evaluated by epifluorescence microscopy (Fig. 4C). Few cells showed Annexin-V staining in control after 6 hours $(7.6 \%)$ compared to UV treated cells (23.6\%). Annexin-V staining was observed in the periphery of cells showing different apoptotic stages. In first stages, cells showed regular membrane surface while in more advanced stages, blebbing and irregularity were observed on 
273 the cell surface (Fig. 4Cb-c). Only $11.3 \%$ of cells presented IP staining in nucleus corresponding to necrotic or dead cells (Fig. 4Cd).

A Externalization of phosphatidyl-serine in hemocytes of Ostrea edulis from Quiberon

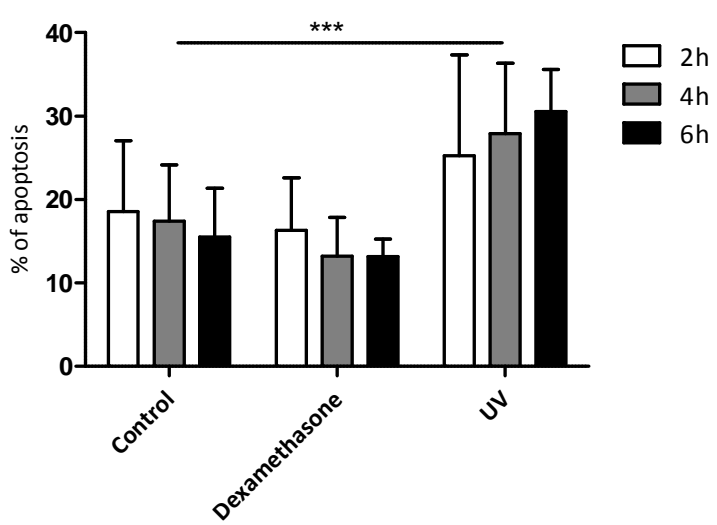

B Externalization of phosphatidyl-serine in hemocytes of Ostrea edulis from Corsica

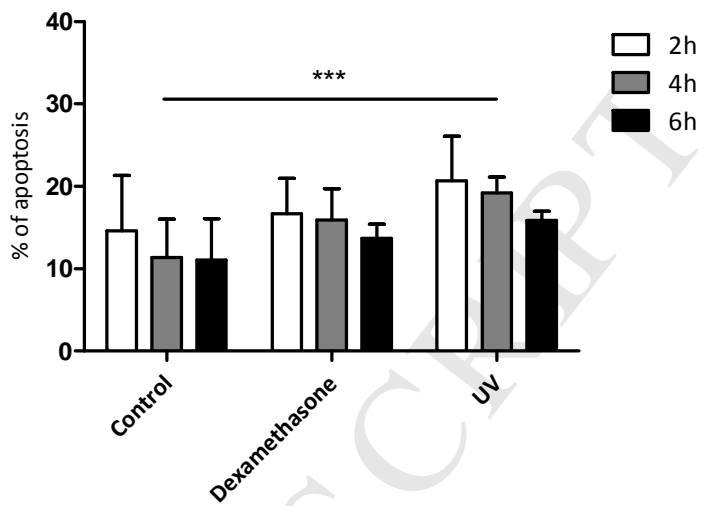

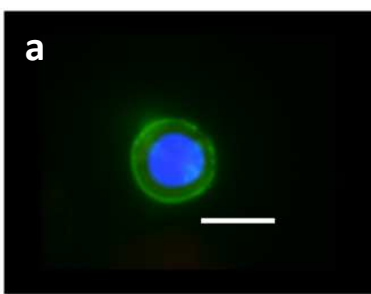

c

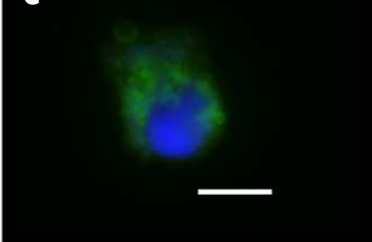

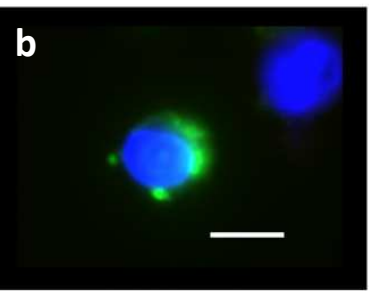

d
276

Figure 4. Modification of plasma membrane in hemocytes of Ostrea edulis. Percentages of AnnexinV positive and PI negative hemocytes of oysters from Quiberon (A) and Corsica (B) nonexposed (=control), exposed to dexamethasone or UV $(* * *(\mathrm{P}<0.001))$. (C) Externalization of phosphatidyl-serine in hemocytes of oysters from Quiberon after 6 hours UV exposure. Different apoptosis stages are visible with an increase of membrane blebbing from a to c. $\mathrm{d}$ show a necrotic cell both PI and Annexin V, bar $=5 \mu \mathrm{m}$. Results represent the mean \pm SD of three experiments.

\subsection{DNA fragmentation}

DNA fragmentation was evaluated using TUNEL assay and by estimating percentage of stained cells under light microscope. Whatever was the origin of the oysters percentage of cells displaying DNA fragmentation was significantly higher in cells treated with UV $(\mathrm{p}<0.001)$ and dexamethasone $(\mathrm{p}<0.001$ and $\mathrm{p}<0.05$ respectively) compared to the control 
(Fig. 5A and B). An increase was also observed between 2 and $6 \mathrm{~h}$ of incubation only for cells treated with dexamethasone and UV.
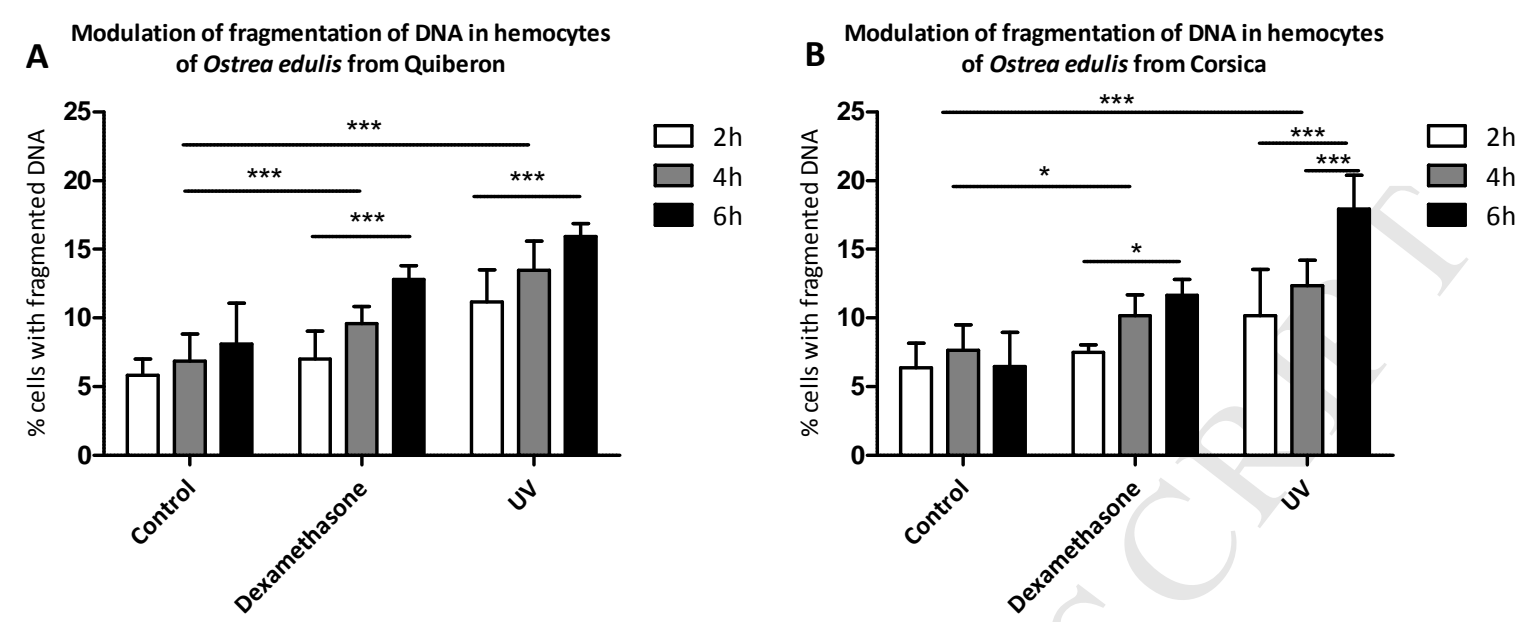

291

Figure 5. Modulation of DNA fragmentation in hemocytes of Ostrea edulis. A and B: Percentages of hemocytes showing fragmented DNA using TUNEL assay in oysters from Quiberon (A) and Corsica (B) non-exposed (=control), exposed to dexamethasone and UV. Results represent the mean \pm $\mathrm{SD}$ of three experiments. *** $(\mathrm{P}<0.001), *(\mathrm{P}<0.05)$

\subsection{Hemocyte populations and apoptosis}

In order to evaluate if UV affected more specifically granulocytes or hyalinocytes, the mean percentage of each hemocyte population was compared between exposed and nonexposed hemocytes from Quiberon and Corsican oysters (Fig. 6A and B). In both oyster groups, the percentage of hyalinocytes was higher than percentage of granulocytes $(p<0.001)$. UV significantly decreased percentages of hyalinocytes and increased percentages of granulocytes at 2 and 4 hours post exposure in hemocytes from Quiberon (Fig. 6A). Percentages were not significantly different between control and UV treated cells for Corsican oysters (Fig. 6B).

In order to test if apoptosis occurred more specifically in granulocytes or hyalinocytes after UV exposure, percentages of Annexin-V labelled cells were compared between hyalinocytes and granulocytes in exposed and control cells. The percentage of Annexin-V labelled cells was significantly higher for granulocytes exposed or non-exposed to UV than for hyalinocytes only for Corsican oysters at 2 hours $(\mathrm{p}<0.001)$ and 4 hours $(\mathrm{p}<0.01)$ posttreatment (Fig. 6D). Whatever was the hemocyte population, UV exposure increased the percentage of apoptotic cells. This difference was significant at $6 \mathrm{~h}$ post exposure $(\mathrm{p}<0.05)$ for 
hyalinocyte for Quiberon oyster (Fig. 6C) and at $4 \mathrm{~h}(\mathrm{p}<0.05)$ for Corsican oyster and for granulocyte at $4 \mathrm{~h}(\mathrm{p}<0.01)$ for oyster from Corsica $($ Fig. 6D).
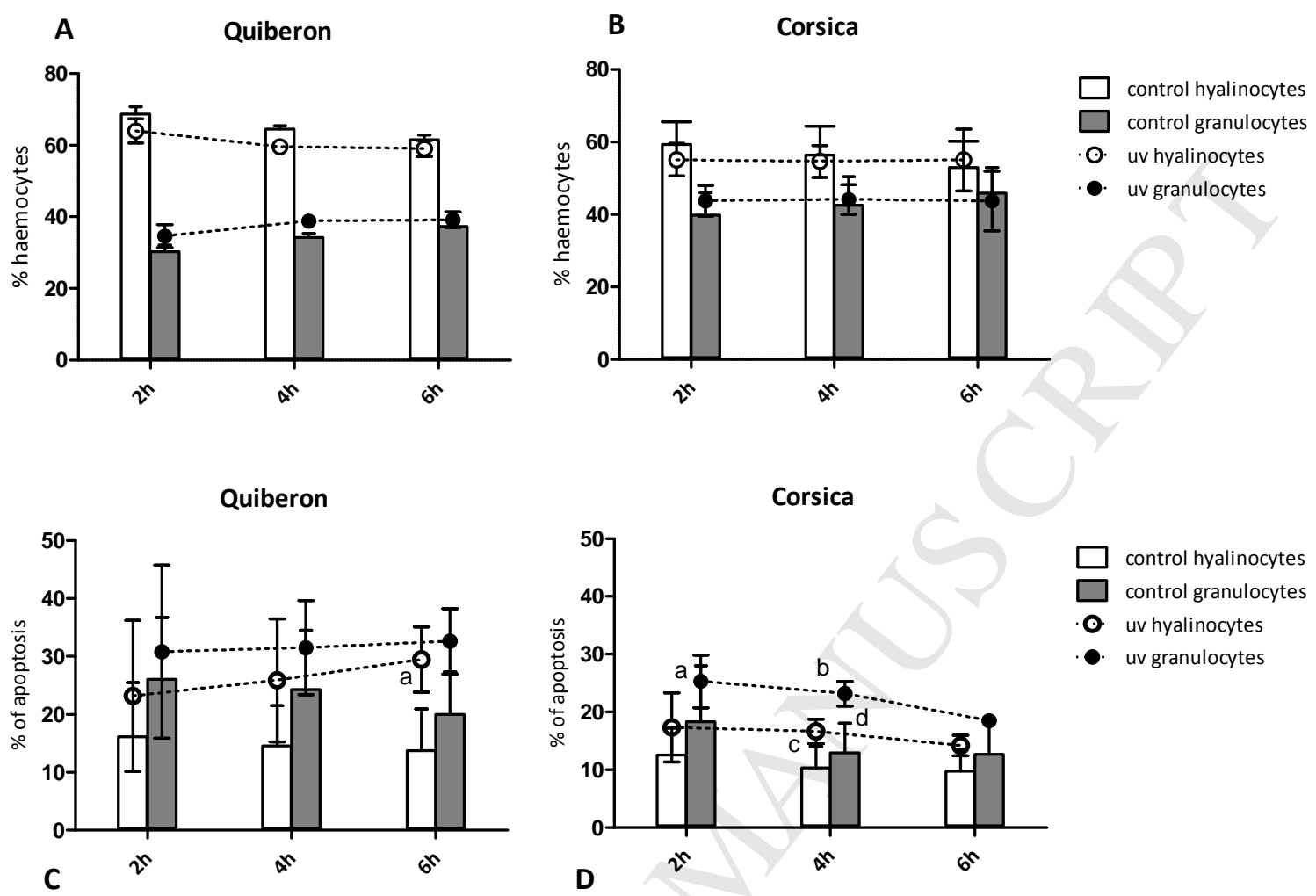

Figure 6. Modulation of apoptosis in hyalinocytes and granulocytes of Ostrea edulis. Temporal variation of percentages of granulocytes and hyalinocytes in suspensions of hemocytes exposed or non-exposed to UV for oysters from Quiberon (A) and Corsica (B) $(\mathrm{a}(\mathrm{p}<0.05)$ between treated and non-treated hyalinocytes). Temporal variation of granulocytes and hyalinocytes apoptosis in hemocytes exposed or non-exposed to UV for oyster from Quiberon (C) and Corsica (D) (a ( $<<0.001)$, $\mathrm{b}(\mathrm{p}<0.01)$ between UV-treated hyalinocytes and granulocytes; $c(p<0.05)$ between treated and nontreated hyalinocytes, $d(p<0.01)$ between treated and non-treated granulocytes). Results represent the mean \pm SD of three experiments.

\subsection{Morphological changes}

To support results obtained using flow cytometry, fluorescence microscopy and TUNEL, UV-exposed hemocytes from Quiberon were also examined by TEM. Different morphological modifications were observed and were used to distinguish between apoptosis and necrosis (Table 1). Most of non-exposed cells showed normal nucleus with noncondensed chromatin and no cytoplasmic modifications (Fig. 7A). After 4 hours of incubation, non-treated samples showed $61 \%$ of living cells (Table 2) while an increase of apoptotic cells was observed in UV-treated samples (44\%) (Table 2). The most important 


\section{ACCEPTED MANUSCRIPT}

modifications concerned the nucleus and consisted of chromatin condensation (Fig. 7B, C and

E) and margination with ring-like shape characteristic of apoptosis (Fig. 7C). Nucleus

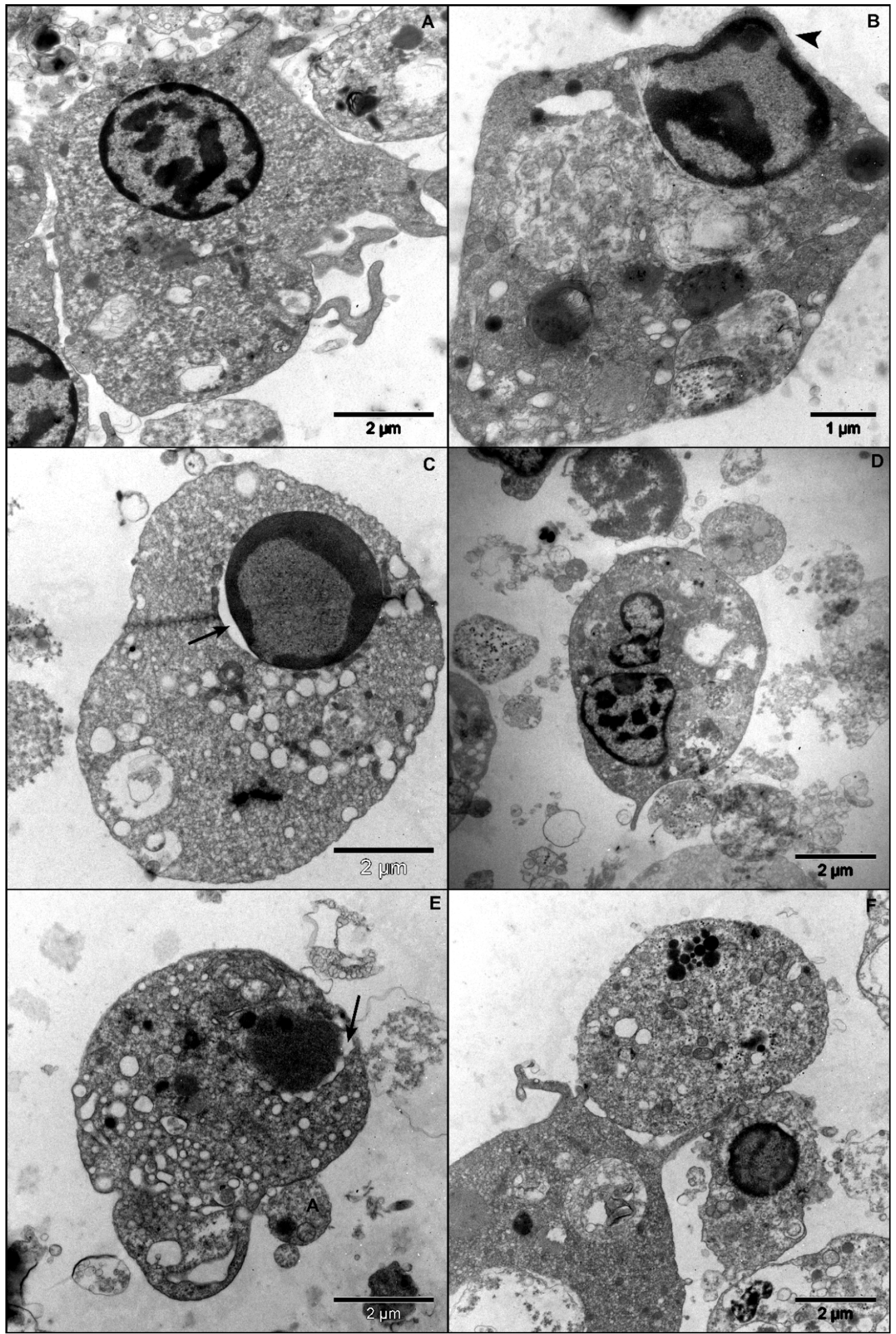




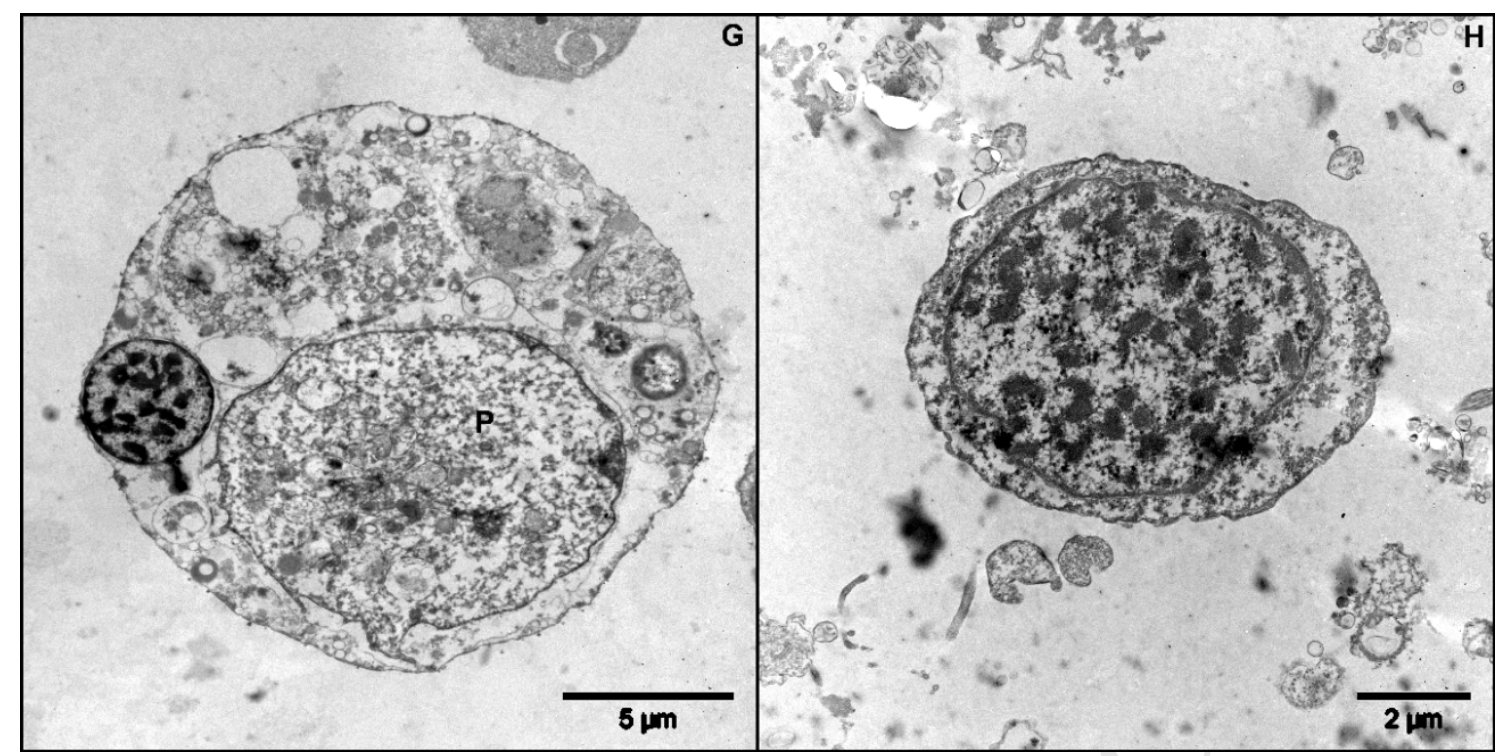

Figure 7. Morphological modifications of hemocytes of flat oysters from Quiberon induced

340

341

342

343

344

345

346

347

condensation was sometimes associated with an enlargement of the perinuclear space (Fig. 7C and E). Deformation and fragmentation of the nucleus could also be noticed (Fig. 7D). In addition to nucleus alteration, some cells showed membrane blebbing and apoptotic bodies (Fig. 7B and E). Pictures interpreted as hemocytes phagocytosing or having phagocytized apoptotic cells were sometimes observed $6 \mathrm{~h}$ after UV-exposure (Fig 7F and G).

Nucleus and DNA modifications allowed distinguishing between cells under secondary necrosis, terminal cell disruption of apoptotic cells, and primary necrosis (Table 1). Both types of cells displayed mitochondrial and cytoplasmic swelling and cytoplasmic membrane damage. However, DNA appeared condensed or nuclei fragmented in secondary necrosis (Fig. 7E) and dissolved in primary necrosis (Fig. 7H).

Based on morphological modifications of Table 1 cells were classified and counted for each condition of cells exposed to UV and at $4 \mathrm{~h}$ for the control. An increase of cells showing morphological modifications typical of apoptosis was observed after UV exposure and was more important after $6 \mathrm{~h}$ than $2 \mathrm{~h}$ (Table 2). More cells under primary and secondary necrosis 

numerous than apoptotic cells (Table 2).

\section{Morphological features}

Apoptosis

Secondary necrosis

Primary necrosis
Loss of surface structure (pseudopodia)

Nuclear fragmentation (karyorrhexis) and/or

Chromatin condensation

Transformation of mitochondria (vesicle formation)

Membrane blebbing

Apoptotic bodies

Chromatin condensation

Nuclear fragmentation

Transformation of mitochondria (swelling)

Cytoplasmic swelling

Damage to the cytoplasmic membrane

DNA dissolution (karyolysis)

Cytoplasmic swelling

Mitochondrial swelling

Damage to the cytoplasmic membrane

\section{Table 1. Main morphological modifications of cell death (according to [34])}

\section{Discussion}

Programmed cell death (apoptosis) is a key host response to stress factors or pathogens. Importance of this mechanism in oysters such as the Pacific cupped oyster Crassostrea gigas is demonstrated by the high number of genes related to apoptosis in its genome including 48 Inhibitor of Apoptosis Proteins (IAPs) [35]. Several works investigated the involvement of this mechanism in $C$. gigas and in the congeneric species $C$. virginica against stress factors such as salinity, heavy metals, toxic algae and pathogens using molecular and cellular approaches and morphological features [6,14-16,35]. Hemocytes of bivalve mollusks play a major role in the immune system and homeostasis [36-38]. These cells are also commonly used in bioassay to evaluate environmental risk assessment and health status of animals $[39,40]$ and apoptosis has been shown to occur in hemocytes from bivalves exposed to stress factors [14-17]. 


\begin{tabular}{|c|c|c|c|c|}
\hline $\begin{array}{l}\text { Control } 4 \text { hours } \\
(\mathrm{n}=59)\end{array}$ & 61 & 27.1 & 3.4 & 8.5 \\
\hline $\begin{array}{l}\text { UV } 2 \text { hours } \\
(\mathrm{n}=36)\end{array}$ & 44.5 & 25 & 8.3 & 22.2 \\
\hline $\begin{array}{l}\text { UV } 4 \text { hours } \\
(\mathrm{n}=25)\end{array}$ & 28 & 44 & 20 & 8 \\
\hline $\begin{array}{l}\text { UV } 6 \text { hours } \\
(\mathrm{n}=28)\end{array}$ & 17.8 & 53.6 & 14.3 & 14.3 \\
\hline
\end{tabular}

Table 2. Percentages of different cells types in hemocytes of oysters from Quiberon

377

Different physical or chemical treatments are known to induce apoptosis in mammal cells like UV [41,42], actinomycine D, dexamethasone and camptothecin [43-45]. UV exposure has also been tested in invertebrates and has been shown to induce apoptosis in mussels [17,21]. In comparison study of apoptosis on $O$. edulis was relatively low [23,25-28].

Several tools are available to study this phenomenon at the cellular level such as flow cytometry and fluorescence microscopy which target specific biochemical changes induced during apoptosis [46-48]. Research works carried out to better understand apoptosis in bivalves usually rely on the use of one cellular tool sometimes associated with ultrastructural description $[6,14,17,49]$. However, association of several tools is necessary to demonstrate apoptosis occurrence $[46,47]$.

In order to confirm that apoptosis occurs in hemocytes of flat oysters, we exposed them to stress factors like UV and dexamethasone and we combined several tools including flow cytometry, TUNEL, fluorescence and transmission electron microscopy. These tools allowed measuring different biochemical changes and describing intracellular changes induced by apoptosis.

Moreover to avoid investigating hemocyte response of a specific oyster population, two groups of genetically distinct oysters [29] were used to collect hemolymph: Corsican and Quiberon oysters. Indeed, it has previously been reported that genetic diversity among oysters can be related to different hemocyte responses [32]. The apoptotic response was measured at 2, 4 and 6 hours post stress exposure in order to test if apoptosis was modulated during the time.

Results showed that UV exposure modified early apoptotic parameters such as calcium cytoplasmic concentration and mitochondrial membrane potential in hemocytes from Quiberon oysters as soon as 2 hours after treatment. Stress of organelles including mitochondria, endoplasmic reticulum and lysosomes might lead to release of calcium into the 
cytoplasm. The increase of cytoplasmic calcium concentration is known to deregulate cells and induce apoptosis [50] as it has been shown in hemocytes of Penaeus monodon subjected to copper exposure [18]. Similarly, perturbation of $\Delta \Psi \mathrm{m}$ has been associated with apoptosis in invertebrates including Drosophila melanogaster and Lymnea stagnalis [8,51]. Our results suggest that like in vertebrate models, UV induce apoptosis through mitochondria and intrinsic pathway in hemocytes of flat oysters [41].

Additionally, UV significantly modified the integrity of cytoplasmic membrane as demonstrated by the increase of phosphatidyl-serine exposure in hemocytes of Quiberon oysters as soon as 2 hours after exposure. These results are in agreement with results obtained in hemocytes of the Mediterranean mussel, Mytilus galloprovincialis after UV treatment [17]. Although phosphatidyl-serine externalization appears as an interesting biochemical feature to detect apoptosis in cells, it does not discriminate between activated apoptosis pathways $[47,48]$.

In tested conditions, caspase activation did not appear significantly modified after UV exposure, even after 6 hours post treatment except in Quiberon oysters. Caspase activation was slightly increased after UV exposure. Caspases activation was measured using a fluorescent probe, FLICA (Fluorescent Labeled Inhibitor of Caspases) Vibrant ${ }^{\circledR}$ which inhibits a range of caspases known in vertebrates. Obtained results suggest that UV induce hemocyte apoptosis independently of caspases pathway but caspases activation could be influenced by the origin of the oysters.

Not only early apoptotic markers but also late parameters like DNA degradation were observed as soon as 2 hours after UV-exposure. DNA degradation is one of the latest step of apoptosis and is irreversible. TUNEL assay has previously been used to describe apoptosis in invertebrate tissues in association with lesions [28] or with pathogens [52,53] and in cells [54].

Hemocytes treated with UV showed various morphological modifications, increasing over the time. These modifications, typical of apoptosis, included chromatin condensation and nuclear fragmentation and sometimes modification of mitochondria and membrane blebbing. UV-exposed cells could also display morphological modifications that seemed to be related to secondary necrosis rather than to primary apoptosis or primary necrosis. Indeed, secondary necrosis shows nuclei alteration typical of apoptosis whereas primary necrosis is associated with DNA dissolution [34]. 
Previous studies showed different apoptotic response in different hemocyte populations like in the mussel Mytilus galloprovincialis and the clam Ruditapes philippinarum [17,55]. In our study, whatever was the origin of the oysters and the tested conditions, cells identified by flow cytometry as hyalinocytes were more abundant than cells identified as granulocytes. These results are in agreement with results obtained in flat oysters from different natural population [31,56]. Moreover, granulocytes appeared more affected by apoptosis than hyalinocytes even without treatment. In our study both types of hemocytes were affected by UV-treatment in the same way in contrast to $M$. galloprovincialis in which hyalinocytes appeared affected earlier than granulocytes [17].

Although dexamethasone is a common apoptosis inducer in various species [44,57], it did not induce significant apoptotic responses in the conditions tested in the present study except an increase of DNA fragmentation $6 \mathrm{~h}$ post exposure. A higher concentration of dexamethasone $(100 \mu \mathrm{M})$ was tested but only increased necrosis. Dexamethasone is known to induce apoptosis after binding to glucocorticoid receptor [58] which has never been identified in oysters. If this receptor lacks in Ostrea edulis, it could explain the lack of induction of apoptosis in our conditions. Moreover, apoptotic signs are generally observed after $8 \mathrm{~h}$ and more generally $24 \mathrm{~h}$ of exposure to dexamethasone [44,57,59] while in our tests we did not maintain hemocytes more than 6 hours.

Flow cytometry analyses were carried out on hemocytes from Quiberon and Corsican oysters. Both groups of oysters showed similar modulation of apoptotic parameters after UV exposure. However, percentages of apoptotic cells were lower in hemocytes of oysters from Corsica than Quiberon and caspase activation did not appear impacted by UV. Although some differences were reported in the apoptosis process depending on the tested population, the apoptotic response of hemocytes to UV was observed in oysters belonging to both populations in the present study. Differences in terms of apoptosis between oyster populations can be related to their genetic differences [29].

Our results confirm that apoptosis is induced in hemocytes of Ostrea edulis by UV exposure. Mitochondria deregulation suggests that cell death is activated through the intrinsic pathway. In mammals, it has been shown that UV can induce apoptosis by different ways, through the intrinsic pathway, the extrinsic pathway or can directly induce DNA fragmentation $[41,60]$.

This work has contributed to establish different techniques to investigate apoptosis in hemocytes of Ostrea edulis. The combination of flow cytometry, TUNEL, fluorescence and transmission electron microscopy allowed confirming the involvement of apoptosis in 
response to UV. These different tools could now be applied in the context of studies investigating apoptosis in flat oysters in response to other stress factors such as pollutant or pathogens known to affect $O$. edulis including Bonamia ostreae.

\section{Acknowledgements}

The Région of Poitou Charentes, France and Ifremer supported these research works. The authors thank P. Phelipot and his colleagues for technical assistance for the maintenance of oysters in Ifremer La Tremblade, France facilities. A. Langlade and Y. Baldi are also acknowledged for supplying flat oysters from Quiberon and Diana, France.

\section{References}

[1] Assunção Guimarães C, Linden R. Programmed cell deaths. Apoptosis and alternative deathstyles. Eur J Biochem FEBS 2004;271:1638-50. doi:10.1111/j.1432-1033.2004.04084.x.

[2] Feldmann G. L'apoptose ou la mort cellulaire programmée. Ann Pathol 1995;15:92-109.

[3] Kiss T. Apoptosis and its functional significance in molluscs. Apoptosis Int J Program Cell Death 2010;15:313-21. doi:10.1007/s10495-009-0446-3.

[4] Sokolova I. Apoptosis in molluscan immune defense. Invertebr Surviv J 2009:49-58.

[5] Goedken M, Morsey B, Sunila I, De Guise S. Immunomodulation of Crassostrea gigas and Crassostreae virginica cellular defense mechanisms by Perkinsus marinus. J Shellfish Res 2005;24:487-96. doi:10.2983/0730-8000(2005)24[487:IOCGAC]2.0.CO;2.

[6] Hughes FM, Foster B, Grewal S, Sokolova IM. Apoptosis as a host defense mechanism in Crassostrea virginica and its modulation by Perkinsus marinus. Fish Shellfish Immunol 2010;29:247-57. doi:10.1016/j.fsi.2010.03.003.

[7] R. Cameron GF. Apoptosis and Its Modulation by Drugs (Handbook of Experimental Pharmacology) Edited by): Springer Verlag, Berlin 9783540661214 Hardcover - Mountainview Books, LLC. vol. 142. Springer Verlag; 2000.

[8] Russo J, Madec L. Haemocyte apoptosis as a general cellular immune response of the snail, Lymnaea stagnalis, to a toxicant. Cell Tissue Res 2007;328:431-41. doi:10.1007/s00441-0060353-7.

[9] Sokolova IM, Evans S, Hughes FM. Cadmium-induced apoptosis in oyster hemocytes involves disturbance of cellular energy balance but no mitochondrial permeability transition. J Exp Biol 2004;207:3369-80. doi:10.1242/jeb.01152.

[10] Auffret M. Morphologie comparative des types hémocytaires chez quelques mollusques bivalves d'intérêt commercial. 1985.

[11] Cheng T. Bivalves. Invertebr. Blood Cells Gen. Asp. Anim. True Circ. Syst. Cephalop., Academic Press; 1981, p. 233-99.

[12] Fisher WS. Structure and Functions of Oyster Hemocytes. In: Brehélin DM, editor. Immun. Invertebr., Springer Berlin Heidelberg; 1986, p. 25-35.

[13] Cima F, Matozzo V, Marin MG, Ballarin L. Haemocytes of the clam Tapes philippinarum (Adams \& Reeve, 1850): morphofunctional characterisation. Fish Shellfish Immunol 2000;10:677-93. doi:10.1006/fsim.2000.0282.

[14] Medhioub W, Ramondenc S, Vanhove AS, Vergnes A, Masseret E, Savar V, et al. Exposure to the neurotoxic dinoflagellate, Alexandrium catenella, induces apoptosis of the hemocytes of the oyster, Crassostrea gigas. Mar Drugs 2013;11:4799-814. doi:10.3390/md11124799.

[15] Renault T, Le Deuff RM, Chollet B, Cochennec N, Gérard A. Concomitant herpes-like virus infections in hatchery-reared larvae and nursery-cultured spat Crassostrea gigas and Ostrea edulis. Dis Aquat Organ 2000;42:173-83. doi:10.3354/dao042173. 
[16] Renault T, Lipart C, Arzul I. A herpes-like virus infects a non-ostreid bivalve species: virus replication in Ruditapes philippinarum larvae. Dis Aquat Organ 2001;45:1-7. doi:10.3354/dao045001.

[17] Romero A, Estévez-Calvar N, Dios S, Figueras A, Novoa B. New insights into the apoptotic process in mollusks: characterization of caspase genes in Mytilus galloprovincialis. PloS One 2011;6:e17003. doi:10.1371/journal.pone.0017003.

[18] Xian J-A, Wang A-L, Ye C-X, Chen X-D, Wang W-N. Phagocytic activity, respiratory burst, cytoplasmic free- $\mathrm{Ca}(2+)$ concentration and apoptotic cell ratio of haemocytes from the black tiger shrimp, Penaeus monodon under acute copper stress. Comp Biochem Physiol Toxicol Pharmacol CBP 2010;152:182-8. doi:10.1016/j.cbpc.2010.04.003.

[19] Wyllie AH, Beattie GJ, Hargreaves AD. Chromatin changes in apoptosis. Histochem J 1981;13:681-92.

[20] Häcker G. The morphology of apoptosis. Cell Tissue Res 2000;301:5-17.

[21] Estévez-Calvar N, Romero A, Figueras A, Novoa B. Genes of the mitochondrial apoptotic pathway in Mytilus galloprovincialis. PloS One 2013;8:e61502. doi:10.1371/journal.pone.0061502.

[22] Renault T, Faury N, Barbosa-Solomieu V, Moreau K. Suppression substractive hybridisation (SSH) and real time PCR reveal differential gene expression in the Pacific cupped oyster, Crassostrea gigas, challenged with Ostreid herpesvirus 1. Dev Comp Immunol 2011;35:725-35. doi:10.1016/j.dci.2011.02.004.

[23] Morga B, Renault T, Faury N, Arzul I. New insights in flat oyster Ostrea edulis resistance against the parasite Bonamia ostreae. Fish Shellfish Immunol 2012;32:958-68. doi:10.1016/j.fsi.2012.01.026.

[24] De Zoysa M, Nikapitiya C, Moon D-O, Whang I, Kim G-Y, Lee J. A novel Fas ligand in mollusk abalone: molecular characterization, immune responses and biological activity of the recombinant protein. Fish Shellfish Immunol 2009;27:423-32. doi:10.1016/j.fsi.2009.06.019.

[25] Martín-Gómez L, Villalba A, Carballal MJ, Abollo E. Identification of relevant cancer relatedgenes in the flat oyster Ostrea edulis affected by disseminated neoplasia. Mar Biotechnol N Y N 2013;15:159-74. doi:10.1007/s10126-012-9472-1.

[26] Martín-Gómez L, Villalba A, Carballal MJ, Abollo E. Cloning and characterization of neoplasiarelated genes in flat oyster Ostrea edulis. Infect Genet Evol 2014;23:138-49. doi:10.1016/j.meegid.2014.02.004.

[27] Martín-Gómez L, Villalba A, Carballal MJ, Abollo E. Molecular characterisation of TNF, AIF, dermatopontin and VAMP genes of the flat oyster Ostrea edulis and analysis of their modulation by diseases. Gene 2014;533:208-17. doi:10.1016/j.gene.2013.09.085.

[28] Mirella da Silva P, Villalba A, Sunila I. Branchial lesions associated with abundant apoptotic cells in oysters Ostrea edulis of Galicia (NW Spain). Dis Aquat Organ 2006;70:129-37. doi:10.3354/dao070129.

[29] Harrang E. Apport des informations moléculaires et cellulaires pour la caractérisation de la résistance de l'huître plate européenne vis-à-vis de la bonamiose, et pour la détection de signatures de la sélection naturelle. Thesis. 2012. http://archimer.ifremer.fr/doc/00127/23785/

[30] Morga B, Arzul I, Chollet B, Renault T. Infection with the protozoan parasite Bonamia ostreae modifies in vitro haemocyte activities of flat oyster Ostrea edulis. Fish Shellfish Immunol 2009;26:836-42. doi:10.1016/j.fsi.2009.03.018.

[31] Xue QG, Renault T, Chilmonczyk S. Flow cytometric assessment of haemocyte sub-populations in the European flat oyster, Ostrea edulis, haemolymph. Fish Shellfish Immunol 2001;11:55767. doi:10.1006/fsim.2001.0335.

[32] Moreau P, Burgeot T, Renault T. In vivo effects of metaldehyde on Pacific oyster, Crassostrea gigas: comparing hemocyte parameters in two oyster families. Environ Sci Pollut Res 2014. doi:10.1007/s11356-014-3162-7.

[33] Negoescu A, Lorimier P, Brambilla E. TUNEL: Improvement and Evaluation of the Method for In Situ Apoptotic Cell Identification. Biochemica 1997:12-7. 
[34] Silva MT, do Vale A, dos Santos NMN. Secondary necrosis in multicellular animals: an outcome of apoptosis with pathogenic implications. Apoptosis Int J Program Cell Death 2008;13:463-82. doi:10.1007/s10495-008-0187-8.

[35] Zhang G, Fang X, Guo X, Li L, Luo R, Xu F, et al. The oyster genome reveals stress adaptation and complexity of shell formation. Nature 2012;490:49-54. doi:10.1038/nature11413.

[36] Canesi L, Gallo G, Gavioli M, Pruzzo C. Bacteria-hemocyte interactions and phagocytosis in marine bivalves. Microsc Res Tech 2002;57:469-76. doi:10.1002/jemt.10100.

[37] Hine P. The inter-relationships of bivalve haemocytes. Fish Shellfish Immunol 1999;9:367-85. doi:10.1006/fsim.1998.0205.

[38] Tripp MR. Molluscan immunity. Ann N Y Acad Sci 1974;234:23-7.

[39] Binelli A, Cogni D, Parolini M, Provini A. Multi-biomarker approach to investigate the state of contamination of the R. Lambro/R. Po confluence (Italy) by zebra mussel (Dreissena polymorpha). Chemosphere 2010;79:518-28. doi:10.1016/j.chemosphere.2010.02.033.

[40] Nicholson S. Ecocytological and toxicological responses to copper in Perna viridis (L.) (Bivalvia: Mytilidae) haemocyte lysosomal membranes. Chemosphere 2001;45:399-407.

[41] Kulms D, Schwarz T. Molecular mechanisms of UV-induced apoptosis. Photodermatol Photoimmunol Photomed 2000;16:195-201.

[42] Murahashi H, Azuma H, Zamzami N, Furuya K-J, Ikebuchi K, Yamaguchi M, et al. Possible contribution of apoptosis-inducing factor (AIF) and reactive oxygen species (ROS) to UVBinduced caspase-independent cell death in the T cell line Jurkat. J Leukoc Biol 2003;73:399-406.

[43] Kasim NR, Kuželová K, Holoubek A, Model MA. Live fluorescence and transmission-through-dye microscopic study of actinomycin D-induced apoptosis and apoptotic volume decrease. Apoptosis Int J Program Cell Death 2013;18:521-32. doi:10.1007/s10495-013-0804-z.

[44] Lee T-H, Nam JG, Lee HM, Kim B-Y, Kang M-K, Bae WY, et al. Dexamethasone Induces Apoptosis of Nasal Polyp-Derived Tissue Cultures Through JNK and p38 MAPK Activation. Clin Exp Otorhinolaryngol 2014;7:112-8. doi:10.3342/ceo.2014.7.2.112.

[45] Wolbers F, Buijtenhuijs P, Haanen C, Vermes I. Apoptotic cell death kinetics in vitro depend on the cell types and the inducers used. Apoptosis 2004;9:385-92. doi:10.1023/B:APPT.0000025816.16399.7a.

[46] Galluzzi L, Vitale I, Abrams JM, Alnemri ES, Baehrecke EH, Blagosklonny MV, et al. Molecular definitions of cell death subroutines: recommendations of the Nomenclature Committee on Cell Death 2012. Cell Death Differ 2012;19:107-20. doi:10.1038/cdd.2011.96.

[47] Kroemer G, Galluzzi L, Vandenabeele P, Abrams J, Alnemri ES, Baehrecke EH, et al. Classification of cell death: recommendations of the Nomenclature Committee on Cell Death 2009. Cell Death Differ 2009;16:3-11. doi:10.1038/cdd.2008.150.

[48] Wlodkowic D, Skommer J, Darzynkiewicz Z. Cytometry of apoptosis. Historical perspective and new advances. Exp Oncol 2012;34:255-62.

[49] Kuchel RP, Raftos DA. In vitro effects of noradrenaline on Akoya pearl oyster (Pinctada imbricata) haemocytes. Fish Shellfish Immunol 2011;31:365-72. doi:10.1016/j.fsi.2011.05.025.

[50] Smaili SS, Pereira GJS, Costa MM, Rocha KK, Rodrigues L, do Carmo LG, et al. The role of calcium stores in apoptosis and autophagy. Curr Mol Med 2013;13:252-65.

[51] Zimmermann KC, Ricci J-E, Droin NM, Green DR. The role of ARK in stress-induced apoptosis in Drosophila cells. J Cell Biol 2002;156:1077-87. doi:10.1083/jcb.20112068.

[52] Sunila I, LaBanca J. Apoptosis in the pathogenesis of infectious diseases of the eastern oyster Crassostrea virginica. Dis Aquat Organ 2003;56:163-70. doi:10.3354/dao056163.

[53] Wu X-G, Xiong H-T, Wang Y-Z, Du H-H. Evidence for cell apoptosis suppressing white spot syndrome virus replication in Procambarus clarkii at high temperature. Dis Aquat Organ 2012;102:13-21. doi:10.3354/dao02532.

[54] Hsu J-P, Huang C, Liao C-M, Hsuan S-L, Hung H-H, Chien M-S. Engulfed pathogen-induced apoptosis in haemocytes of giant freshwater prawn, Macrobrachium rosenbergii. J Fish Dis 2005;28:729-35. doi:10.1111/j.1365-2761.2005.00681.x. 
[55] Prado-Alvarez M, Romero A, Balseiro P, Dios S, Novoa B, Figueras A. Morphological characterization and functional immune response of the carpet shell clam (Ruditapes decussatus) haemocytes after bacterial stimulation. Fish Shellfish Immunol 2012;32:69-78. doi:10.1016/j.fsi.2011.10.019.

[56] Cochennec-Laureau N, Auffret M, Renault T, Langlade A. Changes in circulating and tissueinfiltrating hemocyte parameters of European flat oysters, Ostrea edulis, naturally infected with Bonamia ostreae. J Invertebr Pathol 2003;83:23-30.

[57] Hu H, Kang J, Chen R, Mamuti W, Wu G, Yuan W. Drug-induced apoptosis of Echinococcus granulosus protoscoleces. Parasitol Res 2011;109:453-9. doi:10.1007/s00436-011-2276-9.

[58] Druilhe A, Létuvé S, Pretolani M. Glucocorticoid-induced apoptosis in human eosinophils: mechanisms of action. Apoptosis Int J Program Cell Death 2003;8:481-95.

[59] Ajiro K, Scoltock AB, Smith LK, Ashasima M, Cidlowski JA. Reciprocal epigenetic modification of histone $\mathrm{H} 2 \mathrm{~B}$ occurs in chromatin during apoptosis in vitro and in vivo. Cell Death Differ 2010;17:984-93. doi:10.1038/cdd.2009.199.

[60] Rehemtulla A, Hamilton CA, Chinnaiyan AM, Dixit VM. Ultraviolet radiation-induced apoptosis is mediated by activation of CD-95 (Fas/APO-1). J Biol Chem 1997;272:25783-6. 